\title{
Evaluation of Genetic Mixtures of Sorghum Lines for Anthracnose Resistance Management
}

\author{
Rodrigo V. da Costa ${ }^{1}$, Carlos R. Casela ${ }^{2}$, Laércio Zambolim ${ }^{1}$, Fredolino G. Santos ${ }^{2}$ \\ \& Francisco X. R. do Vale ${ }^{1}$ \\ ${ }^{1}$ Departamento de Fitopatologia, Centro de Ciências Agrárias, Universidade Federal de Viçosa, Av. P. H. Roelfs s/n, \\ CEP 35571-000, Viçosa, MG; ${ }^{2}$ Embrapa Milho e Sorgo, Cx.Postal 151, CEP 35701-970, Sete Lagoas, MG, \\ e-mail: casela@cnpms.embrapa.br
}

(Accepted for publication on 08/09/2004)

Corresponding author: Carlos R. Casela

COSTA, R.V., CASELA, C.R., ZAMBOLIM, L., SANTOS, F.G. \& DO VALE, F.X.R. Evaluation of genetic mixtures of sorghum lines for anthracnose resistance management. Fitopatologia Brasileira 30:525-526 2005.

\begin{abstract}
The main objective of this work was to evaluate the diversification of sorghum (Sorghum bicolor) populations as a way to manage resistance to the sorghum anthracnose fungus Colletotrichum graminicola. A total of 18 three-way hybrids were obtained by crossing six single cross male-sterile F1 hybrids, derived by crossing A (non restorer sterile cytoplasm) and B (non restorer normal cytoplasm) lines, with three fertile R (restorer) lines, previously evaluated for their differential reaction to the pathogen. Variation in the level of resistance was observed, as indicated by the values of the area under the disease progress curve (AUDPC) obtained for each hybrid. Lines contributed differently to the level of resistance of each hybrid. All hybrids in which CMSXS169R was the male progenitor were classified as highly resistant. Some hybrids had a level of resistance superior to the maximum levels of each line component individually.
\end{abstract}

Additional keywords: Colletotrichum graminicola, resistance management.

\section{RESUMO}

Avaliação de misturas genéticas de linhagens de sorgo para o manejo da resistência à antracnose

Este trabalho teve como objetivo avaliar a possibilidade de se utilizar a diversificação de populações hospedeiras de sorgo (Sorghum bicolor) como uma estratégia alternativa para o manejo da resistência ao agente causal da antracnose Colletotrichum graminicola. Foram avaliados 18 híbridos triplos obtidos a partir do cruzamentto entre seis híbridos F1, resultantes do cruzamento entre linhagens A (com citoplasma macho-estéril) e linhagens B (com citoplasma fértil não restaurador de fertilidade) e três linhagens R (restauradoras), selecionadas com base na sua reação diferencial ao patógeno. Observou-se uma variação no nível de resistência dos híbridos avaliados. As linhagens contribuíram diferentemente em nível de resistência de cada híbrido triplo e todos aqueles em que a linhagem CMSXS169R foi utilizada como o progenitor masculino foram classificados como altamente resistentes a $C$. graminicola. Alguns cruzamentos apresentaram um nível final de resistência superior ao das três linhagens componentes do híbrido avaliadas individualmente.

Palavras-chave adicionais: Colletotrichum graminicola, resistência.

Anthracnose caused by Colletotrichum graminicola (Ces.) G. W. Wils. (syn. C. sublineolum Henn. In Kab. \& Bubák) is one of the most damaging diseases of sorghum (Sorghum bicolor L. Moench), especially in the warm and humid areas of the world (Harris \& Johnson, 1967; Ali \& Warren, 1992). The disease is present in all of the major sorghum growing areas of Brazil where it causes severe losses in yield and quality of grain and fodder, depending on the susceptibility of the cultivar and the severity of the epidemics (Guimarães et al., 1999; Casela et al., 2001).

Genetic resistance, the most efficient way to control the disease, has been transitory due to the high variability in the population of this pathogen (Cardwell et al., 1989; Casela et al., 2001). The instability of vertical resistance to $\mathrm{C}$. graminicola has promoted the search for more stable and durable forms of resistance. Dilatory resistance, characterized by a slow rate of disease development has been demonstrated and used for the control of anthracnose in sorghum (Cardwell et al., 1988; Guimarães et al., 1999). One alternative for highly variable pathogens such as $C$. graminicola, is the diversification of the host population, as a way to stabilize the pathogen population and to slow down the rate of disease development (Guimarães et al., 1998). The use of dynamic multilines, through the development of genetic mixtures, can be a way to diversify the host population and to manage resistance genes (Wilson et al., 2001). The main objective of this work was to evaluate the diversification of sorghum populations, through the development of three way hybrids, as a strategy to manage resistance to $C$. graminicola.

A total of 18 three-way hybrids were obtained by crossing six single cross male-sterile F1 hybrids, derived by crossing A (non restorer sterile cytoplasm) and B (non restorer normal cytoplasm) lines, with three fertile R (restorer) lines, previously evaluated for their differential reactions to the 
pathogen. The 18 hybrids and pure stands of the seven parental lines, totaling 25 treatments, were evaluated in the field for anthracnose development, under natural epidemics, in a randomized complete block design with three replications.

Hybrids and pure stands were planted in two row plots, separated by two rows of corn (Zea mays L.) to reduce interplot contamination. Rows in each plot were $6.0 \mathrm{~m}$ long, $0.9 \mathrm{~m}$ apart with $0.2 \mathrm{~m}$ between plants. Spreader rows were formed by the susceptible genotype BR009 (Tx623), planted $0.5 \mathrm{~m}$ apart and in front of each block.

Disease severity was evaluated on a weekly basis, starting just after first symptoms were observed in the most susceptible genotypes. Evaluations were made according to the diagrammatic scale of Sharma (1983) and all plants, except the first three at both ends of each plot, were rated for disease severity. Disease severity rates were then used to calculate the area under the disease progress curve (AUDPC) according to Torres \& Ventura (1991).

Variation in the level of resistance was observed, as indicated by the values of AUDPC obtained for each genotype evaluated. Hybrids could be separated into three major groups: susceptible, intermediates and resistant. The lines contributed differently to the level of resistance of each hybrid. All crosses with the male progenitor CMSXS169R resulted in highly resistant hybrids, whereas only $50 \%$ of crosses with CMSXS116R and 33.4\% of crosses with CMSXS182Rr were classified as highly resistant (data not shown). Some hybrids had a level of resistance superior to the levels of each line component individually; for example, the hybrid derived from the crosses of the lines CMSXS210A, CMSXS 221B, and CMSXS182R was classified as resistant although CMSXS210A, and CMSXS215B, were highly susceptible and CMS182R had only a moderate level of resistance (Figure 1).

The genetic mixture approach is based on the fact

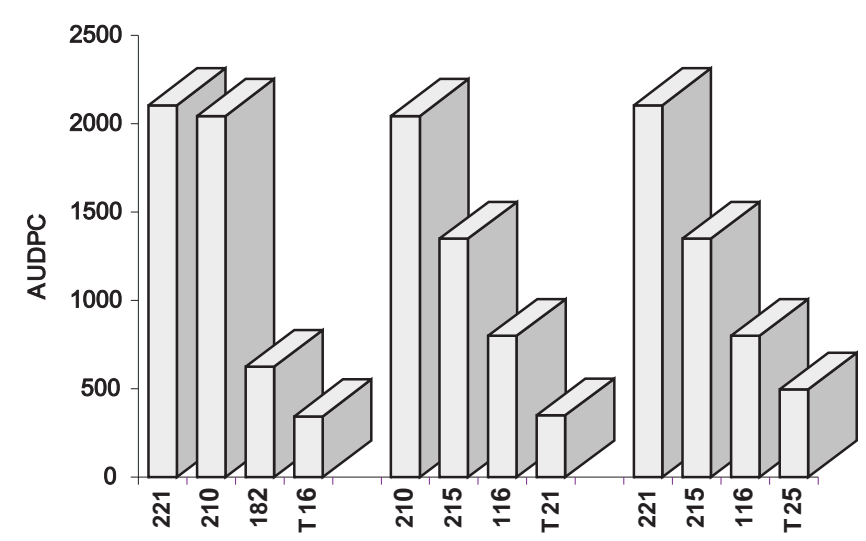

FIG. 1-Area under disease progress curve of anthracnose on three sorghum (Sorghum bicolor) lines and respective three-way hybrids. 1/T16 - Hybrid [(CMSXS221AxCMSXS210B)xCMSXS182R] T21 - Hybrid [(CMSXS210AxCMSXS215B)xCMSXS116R] T25 - Hybrid [(CMSXS221AxCMSXS215B)xCMSXS116R] that, in the population of the hybrid, plants with different resistant gene combinations will hinder the disease development and stabilize the pathogen population. This strategy encompasses two basic principles of gene deployment strategies for resistance to highly variable pathogens: gene pyramiding and cultivar mixtures (Wilson et al., 2001). Another advantage of this method is that it will allow for the use of lines with good agronomic traits and combining ability which otherwise, due to their susceptibility, would not be used in the development of hybrids in a sorghum breeding program, as was observed in this study.

The ability of the pathogen to respond to the resultant diversity in the host population are under evaluation as a way to predict the possibility of breakdown of resistance through the development of complex races in three-way sorghum hybrids.

\section{LITERATURE CITED}

ALI, M.E.K. \& WARREN, H.L. Anthracnose of sorghum. Pages 203-208 in Sorghum and Millet Diseases: a Second World Review. De Milliano, W. A.J., Frederiksen, R.A. \& Bengston, G.D. (Eds.) Patancheru, A.P. 502324, India. International Crop Research Institute for the Semi-Arid Tropics. 1992.

CARDWELL, K.F., COLLINS, S.D. \& FREDERIKSEN, R.A. Dilatory resistance character of sorghum hybrids as measured by area under disease progress curve. Biological and Cultural Tests 3:36. 1988

CARDWELL, K.F., HEPPERLY, P.R. \& FREDERIKSEN, R.A. Pathotypes of Colletotrichum graminicola and seed transmission of sorghum anthracnose. Plant Disease 73:255-257. 1989.

CASELA, C.R., SANTOS, F.G. \& FERREIRA, A.S. Reaction of sorghum genotypes to the anthracnose fungus Colletotrichum graminicola. Fitopatologia Brasileira 26:197-200. 2001.

GUimarães, F.B., CASELA, C.R., SANTOS, F.G. DOS \& FERREIRA, A.S. Controle da antracnose do sorgo através da utilização de misturas de cultivares. Summa Phytopathologica 24:131-135. 1998.

GUIMARÃES, F.B., CASELA, C.R., SANTOS, F.G., PEREIRA, J.C.R. \& FERREIRA, A.S. Avaliação da resistência de genótipos de sorgo a antracnose. Summa Phytopathologica 25:308-312. 1999.

HARRIS, H.B. \& JOHNSON, J.B. Sorghum anthracnose symptoms, importance and resistance. In: Proceedings of the Fifth Biennial Grain Sorghum Research and Utilization Conference, sponsored by the Grain Sorghum Producers' Association (GSPA) and Sorghum Improvement Conference of North America, 1967. pp.48-52.

SHARMA, H.C. A technique for identifying and rating resistance to foliar diseases of sorghum under field conditions. Proceedings, Indian Academy of Sciences (Plant Sciences) 92:271-278. 1983.

TORRES, J.C. \& VENTURA, J.A. Um programa para calcular a área e o volume abaixo da curva de progresso da doença. Fitopatologia Brasileira 16:52. 1991.

WILSON, J.P., GATES, R.N. \& PANWAR, M.S. Dynamic multiline population approach to resistance gene management. Phytopathology 91:255-260. 2001. 